\title{
CONFLICT OF INTEREST IN GREEN OPEN SPACE PLANNING IN DENPASAR CITY
}

\author{
I Ketut Mudra $^{1^{*}}$ and Ni Ketut Ayu Siwalatri ${ }^{2}$ \\ ${ }^{1}$ Doctoral Study Program of Engineering Science, Faculty of Engineering, Udayana University \\ Kampus Sudirman, Denpasar-Bali, Indonesia. \\ ${ }^{2}$ Master Study Program of Architecture, Faculty of Engineering, Udayana University \\ Kampus Bukit Jimbaran, Badung-Bali, Indonesia. \\ ikmudra@unud.ac.id
}

\begin{abstract}
This research is a response to the regional regulations high intensity violations phenomenon in governing the green open space in Denpasar City. The emergence of this phenomenon as a consequence of a regional regulation core, which is policy taken by the government as a result of synergy, compromise or even competition -in this research called as conflict- between ideas, theories, ideologies and interests. These various interests are the research's main focus to aim the conflict of interest better understanding in open planning green space of Denpasar City, as part of public policy oriented to the relationship of the planning and development systems of the city. This research is designed using qualitative approach with interpretive method. Problems are examined through three elements of research, namely: (1) green open space in the context of spatial planning and formation; (2) interests involved in green open space planning; and (3) the influence of various interests on the existence of green open space. The findings of the study are that in the context of regional spatial planning, the emergence of violations phenomenon of regional regulations regarding green open spaces in the Denpasar City occurs because of three main conflicts, based on: (1) economic conflict; (2) political conflict; and (3) cultural conflicts. These three main conflicts then trigger the emergence of land use conflicts that threaten the existence of green open spaces in Denpasar City.
\end{abstract}

Keywords: Conflict of interest, spatial planning, green open space, Denpasar City

\section{INTRODUCTION}

The city development is a fairness and even a necessity, in line with the changing times and demands of community needs through a very diverse process. Zahnd (2006) calls it the city not a product but a process, so that city planning should not only concentrate formally on the city form, yet must provide structural concentration that is on a system that runs in dynamic space and time. The emphasis is on the process that is very important and determines the direction of the city development.

The process of urban development will be closely related to the elements that form the city. Shirvani (1985) identified eight physical elements of urban design, namely: (1) land use; (2) building form and massing; (3) circulation and parking; (4) open space; (5) pedestrian ways; (6) activity support; (7) signage; and (8) preservation and conservation. For almost the last decade, the discourse on green open space (GOS) has become an important issue in line with human fear of the global warming effects. The greenhouse effect is frequently considered as the main cause of global warming, even though the lack of GOS is rated the trigger as well.

One of the biggest challenges in maintaining the availability of GOS in urban areas is agricultural land to non-agriculture at highly rate conversion. Indonesian Ministry of Agriculture data (2013) shows that the irrigated rice fields conversion in Indonesia continues to increase. During the 20082012 period, irrigated rice fields decreased by $410,894.18 \mathrm{Ha}$ or $102,723.45 \mathrm{Ha}$ annually. Meanwhile, Bali Provincial BPS data (2013) noted that during the period 2002-2012, the paddy fields conversion in Bali reached 4,151 $\mathrm{Ha}$ or 415.10 Ha per year (SriaGOSa, et al., 2015). The same thing was expressed by Suparta, the HKTI Bali Chairman, who said the rate of land 
conversion in Bali reached 600 to $1,000 \mathrm{Ha}$ each year (Bali Post, March 20, 2017).

The phenomenon of the irrigated rice fields conversion in Bali is not only triggered by population growth, but also driven by the increasingly rapid development of the tourism sector. Moreover, Suparta (Antara Bali, 2012) asserted that the green belt area at highly rate violation in Bali proves that the government indecision is occured to enforce regional regulations as a legal protection to conserve the area out of development and land conversion. On the Bali's island, the paddy fields conversion or green lane areas violation is the most rapid in the Badung, Gianyar, Tabanan, and Denpasar City's district.

From all four regions mentioned above, violations of the area designated as the highest intensity GOS occurred in the Denpasar City area. In fact, to regulate the GOS, the Denpasar City Government already has a set of rules in the form of city-scale Regional Regulations (so called Perda) and Mayor Regulations (so called Perwali) for the scope of sub-districts and strategic areas. However, the existing rules and regulations seem to be powerless in facing the violations that occured.

Moving on from the case of the above violation types, there are two key factors that play an important role, namely the institution and the rule of law. The mentioned institution is the government, while the legal rules will refer to the regulations set by the government in the form of policies. According to Suharto (2008) as an instrument of government, policy is not only in the sense of government which only concerns the state apparatus, but governance that touches on public resource management as well.

Every policy decided by the government is the result of synergy, compromise or even competition between ideas, theories, ideologies and interests (Yunus, 2006). The occurrence of conflicts of interest as a result of large scale urbanization, indicates if similar conflicts also occur on a smaller scale, especially in GOS planning. For this reason, the main focus of the research is related to conflicts of interest in GOS planning in Denpasar City that involve many parties, as part of public policy oriented to the relationship of the planning and development system of the city. This problem will be examined through three elements of research, namely: (1) GOS in the context of spatial planning and formation; (2) interests involved in GOS planning; and (3) the influence of various interests on the existence of GOS.

The target of this research is to formulate what interests are involved and conflict in the GOS planning and its implications for the existence of GOS in Denpasar City. In addition to discussing topics with urgent handling priorities, this research is also holistic and has authenticity related to the scientific discipline to be studied. Its fundamental contribution is the discovery of new scientific phenomena in different development contexts, as well as enriching the scientific discipline of architecture-urban design in the context of spatial planning and development with a condition of social and cultural uniqueness.

\section{METHOD}

\section{Research approach}

This study was designed using qualitative methods. Whereas to understand the conflict of interest involved in GOS planning in Denpasar City an interpretive approach will be used. The choice of this approach is supported by the opinion of Denzin and Lincoln (2000) in Yusuf (2014) who emphasize that in qualitative research uses two approaches, namely interpretative and naturalistic. This means learning something in their natural settings, and trying to make sense or interpretation of phenomena in the context of its meaning.

\section{Research sites}

The research location is generally included in the administration area of Denpasar City, Bali Province. Specifically, the location of the study will be focused on the area designated as GOS in Denpasar City through Regulation (Perda) Number 27 of 2011 consisting of GOS on sites, GOS in residential environments, and city-scale GOS.

\section{Types and data sources}

This study uses qualitative data types supported by quantitative data. Qualitative data are information about geographical aspects, historical aspects, demographic aspects, religious and socio-cultural aspects, economic aspects, and the physical spatial aspects of Denpasar City. Specifically information about GOS is 
summarized in the legal aspects (legal-formal) of GOS planning, as well as the direction of GOS planning and development in Denpasar City. Quantitative data consisting of numbers acts as explanatory qualitative data, in the form of geographical data, demographic, spatial conditions, as well as data on the distribution and extensive composition of GOS in Denpasar City.

Data sources consist of primary data and secondary data. Primary data were obtained from the first source, namely information about GOS in Denpasar City through direct observation techniques both observation, measurement, and depictions in the form of photographs of physical conditions in the field. Secondary data is chosen through indirect sources, in the form of literature related to research focus, documents and research reports both printed and electronic.

\section{Research instruments}

For qualitative research, the instruments used in data collection depend more on researchers as data collection tools. Researchers are considered as the main instrument because researchers can assess the situation and can make decisions. Research instruments are also defined as tools or devices used to support a whole series of activities, both during the data collection process and during data processing (Moleong, 1994). In this study, the research instruments used to collect data were check lists, interview guidelines, cameras, recorders and a computer.

\section{Data collection methods and techniques}

Data collection uses qualitative data collection techniques. Data collection was carried out directly on the object / location of the study through several techniques, namely: (1) observation, carried out by direct observation on the object of research, namely GOS in Denpasar City with a check list guide and notes assisted by the use of a recording device in the form of a camera; (2) interviews with informants who are considered competent in this research field, as well as informants who are determined by accidental, namely the GOS user community encountered during the observation, hereinafter referred to as the respondent; and (3) documentation, carried out to obtain relevant information related to research objectives, obtained from literature studies, government documents, and personal documentation.

\section{Data analysis methods and technique}

Data analysis is carried out qualitatively by interpretation, which describes and explains the data obtained from the data collection results and transcribed in writing which includes three steps, namely: (1) data editorial, starting with reducing data, both primary data from interviews and observations field and secondary data obtained from the relevant literature and government agencies to be selected according to the research objectives. The results of in-depth interviews were selected by coding the transcripts of interviews, so that the research could be more focused on getting the results essence of interviews that were in line with the research objectives; (2) data presentation, in the form of narrative text assisted by the use of matrices or tables to make it easier to reveal the relationship data between the details of each section; and (3) withdrawal of conclusions, carried out in the narrative texts presentation form that were verified during the research took place by finding new data that was more in-depth, so that finally a valid conclusion could be drawn.

\section{Methods and techniques of presentation of data analysis results}

The presented data is a set of information arranged so as to provide the possibility of drawing conclusions and taking action. The results analysis presentation was carried out qualitatively in the form of narrative text with descriptive techniques, so as to obtain a clear and profound picture of the research carried out.

\section{RESULTS AND DISCUSSION}

\section{Green open space (GOS) in the context of regional spatial planning}

Public space can create the character of the city and generally has the function of social interaction for the community, people's economic activities and a place of cultural appreciation. The city's economic development is increasing, causing many investors to target the city's public spaces as a place of business because it is considered more profitable (Darmawan, 2005). This understanding of public space is important to understand from the start, considering the object of study in this study is GOS which according to Carr (1992) is one typology of public space.

GOS types can be distinguished on Protected GOS and Fostered GOS. GOS Protected is a 
wider space or area, either in the form of a longitudinal / lane or clustered area, where the use is more open / public, dominated by plants that grow naturally or cultivated plants. The protected green area consists of nature reserves on land and islands, protected forests, forest tourism, agricultural areas, rice fields, mangrove forests, and so on. GOS Guidance is a wider space or area, either in the form of elongated / lane or clustered areas, where the use is more open / public, with the land surface dominated by artificial pavement and a small portion of plants. Open green areas / spaces are built as an effort to create a balance between built space and green open space that functions as the lungs of the city, water infiltration, prevention of air pollution, and protection of flora (Hakim, 2000).

In the context of spatial planning, national GOS arrangements are stipulated in legal products in the form of: (1) Constitution (so called UndangUndang) Number 26 of 2007 concerning Spatial Planning; (2) Ministry of Home Affair Regulation (so called Peraturan Menteri Dalam Negeri) Number 1 of 2007 concerning Green Open Spatial Planning for Urban Areas; and (3) Ministry of Public Works Regulation (so called Peraturan Menteri Pekerjaan Umum) Number 05 / PRT / M / 2008 concerning Guidelines for Provision and Use of Green Open Space in Urban Areas. Meanwhile for the local scale of Bali, the arrangement of the GOS was determined through the Bali Provincial Regulation (so called Perda Provinsi Bali) Number 16 of 2009 concerning the Bali Provincial Spatial Plan (RTRW) for 20092029.

As a basic element of regional spatial planning, Bali is very interested in the availability of the ideal GOS in a sustainable manner. Especially in the development of the tourism sector with its unique social culture as the main attraction, causing the function and role of the GOS to become more significant in accommodating the new cultural and cultural heritage born of the creative thoughts of the Balinese people. This statement is supported by the fact that the results of cultural works and the form of cultural activities will use GOS as one of the containers (Mudra, 2016).

Given the importance of the functions and roles of GOS as mentioned above, the Denpasar City Government made GOS as one of the basic elements of regional spatial planning through Bali Provincial Regulation Number 27 of 2011 concerning the Denpasar City Spatial Plan (RTRW). GOS in the regional regulation provision which is the research object included in one type of protected area with the provisions of paragraph 6 article 42 as follows, namely:

1. GOS is developed in the form of area/area as well as longitudinal/lane, which is dominated by plants that are fostered for the certain habitats protection function, and/or urban facilities, and/or security of infrastructure networks, and/or agricultural cultivation.

2. Provision of GOS, consisting of:

a. GOS in the site consists of: (1) GOS of the yard on housing; (2) GOS office yards, shops and businesses; and (3) GOS in a building roof garden form.

b. GOS in a residential environment, consisting of: (1) GOS in the form of a residential scale garden; and (2) GOS in the form of an Environmental Unit or Banjar park.

c. GOS on a city scale, consisting of: (1) GOS in the form of a Village/Village scale park or Environmental Unit; (2) GOS in the form of a park on the scale of several villages/sub-districts or Sub BWK; (3) GOS in the form of a district-level park or BWK; (4) GOS City Park; (5) GOS Forest City; (6) Green Belt GOS or agriculture/ rice fields; (7) GOS Great Forest Park; (8) GOS green lane road; (9) GOS Pedestrian space; and (10) GOS of certain functions such as coastal borders, river borders, high voltage lines, setra/graveyards.

d. GOS is developed covering an area of approximately 4,700 (four thousand seven hundred) hectares or $36 \%$ (thirty six percent) of the city area, consisting of Public GOS and Private GOS.

3. GOS Public, developed with an area of approximately 2,480 hectares or $20 \%$ of the city total area in the form of city parks, city recreation parks, sports fields, green road lanes, coastal borders, river borders, mangrove forest (so called) Tahura Ngurah Rai, urban forests, graveyard, estuary dams and ecotourism rice fields.

4. GOS Privat, was developed covering an area of approximately 2,220 hectares or $16 \%$ of the total area in the form of rice fields, mixed gardens and home and office gardens.

5. Development of GOS rice fields ecotourism consists of: 
a. natural recreation development consists of jogging track, trekking, cycling, outbound activities, campgrounds, natural schools, fishing ponds, small industry activities, arts stage and other passive recreational activities;

b. development of Flora Tourism or Flower Garden such as nurseries, sale of

collection/special plants or natural schools related to agriculture in rice fields around the city center;

c. urban agriculture agribusiness development consists of ceremony material (so called upakara) plants development, ornamental plants, aquaculture, fishing and others; and

d. development of buildings related to crop

recreational activities such as restaurants, stage arts.

6. GOS distribution which is an integral part of this local regulation is presented in Figure 1.

7. The broad composition of public and private GOS as an integral part of this local regulation is presented in Table 1 .

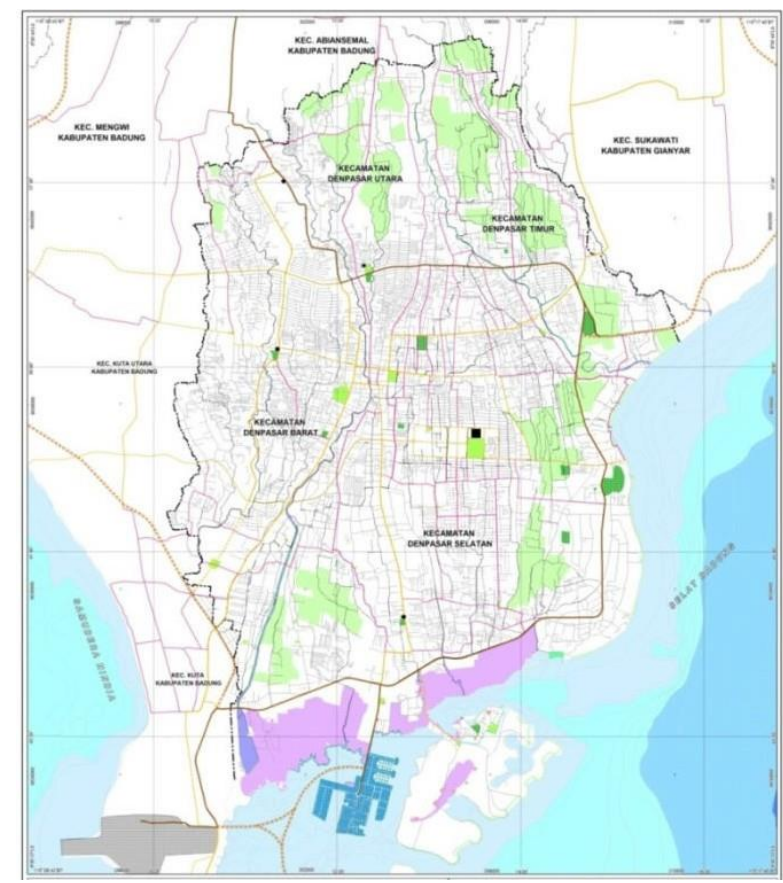

Figure 1. Green open space distribution map in Denpasar City

Source: Appendix of Perda Kota Denpasar No. 27 of 2011
Table 1. Composition of public and private green open space in Denpasar City

Source: Appendix of Perda Kota Denpasar No. 27 of 2011

\begin{tabular}{clcc}
\hline No & Space Function & $\begin{array}{c}\text { Area of } \\
\text { Space } \\
(\mathrm{Ha})\end{array}$ & $\begin{array}{c}\text { Area of } \\
\text { Space } \\
(\%)\end{array}$ \\
\hline 1 & Green Open & $2.341,48$ & 18,32 \\
2 & $\begin{array}{l}\text { City } \\
\text { Green Open } \\
\text { Space Private }\end{array}$ & $2.294,60$ & 17,96 \\
& $\begin{array}{l}\text { City } \\
\text { Total Area of }\end{array}$ & & \\
3 & $\begin{array}{l}\text { Green Open } \\
\text { Space City }\end{array}$ & $4.636,08$ & \\
Denpasar City & & \\
5 & City Green Open & & \\
& Space & \\
\hline
\end{tabular}

The mandate of the law obliges to provide a minimum GOS proportion of $30 \%$ and a public GOS of at least $20 \%$ of the city total area, causing the GOS existence to be very significant in the framework of regional spatial planning in the region, city, region and environment. But in the midst of a very significant existence and position, as one of the public space typologies of GOS planning in many cases it is actually made sober, with the aim of only fulfilling the proportion of $30 \%$ and $20 \%$. GOS planning is frequently not integrated with regional spatial planning as a whole, causing the position and existence of the GOS to be very weak and vulnerable to manipulation. This is evidenced by the high change in the GOS function into a built area, even though it has been expressly prohibited by regional regulations.

\section{Green open space (GOS) in the formation of regional spatialities}

The elements forming the city will be closely related and very decisive in the process of urban development. According to Shirvani (1985), one of the eight urban design physical elements is open space and green open space. If urban design is seen as part of macro space planning, the GOS has an important role and is a basic element in the spatial physical formation.

Spatial planning is closely related to human civilization, culture, and capabilities including the science and technology development. The 
community culture form will accumulate into physical form including the life forms that occur in it. In the context of regional spatial formation, especially in Bali, Suartika (2013) illustrates the GOS as building a social space that reflects a clash of values, not a conflict between west and east but between strength and lifestyle, where the capitalism evolution has a serious impact on traditional Hindu society drive some of its activities towards extinction. Traditional social life in Bali conceptualizes the public space realm and space typologies that still approach Balinese values and ways of life more than capitalist markets. Paradoxically, while capitalism is legally protected, traditional spatial practices and traditions are not.

Similar opinion also states that there is a tendency of the world city development in the 21 st century which leads to the development as a capitalist city. City spaces are all contested by all actors, including government, society (intellectuals/ academics), spatial practitioners, architects, nongovernmental organizations and capital/investor power (Lefebvre, 1974, 1991; Aminah, 2015).

The above opinion provides an overview of the strategic and important GOS role in spatial planning and the formation of physical spatial forms, both at the global and local levels. Therefore, the GOS existence protection becomes very important and needs to be improved through defense mechanisms against the worst excesses of capitalism with all its commodification forms. In the case of Denpasar City, the GOS protection is highly urgent to be carried out considering the function and physical city rapid growth as a result of the increasing community economic development.

\section{Conflict of interest in green open space (GOS) planning}

It has been explained earlier that any policy decided by the government is the result of synergy, compromise or even competition - in this study the term is conflict-between ideas, theories, ideologies and interests. In connection with this interest, Aminah (2015) asserts that the practice of urban spatial planning is not merely the economic and political actors interest arrangement, but also concerns the power relations of actors as regulators, investors, and users. In that relation, negotiations between actors become determinants of the structuring politics practise on a space, both for the public interest where all the community members can use the space fully or for commercial purposes and can only be accessed by certain groups of people.

The occurrence of a conflict of interest is called the "megapolitanization" process, that is, a process of being urban is the same as the process of urbanization itself, only on a different scale. The urbanization process emphasizes the cities existence individually with a smaller spatial scale, while megapolitanization emphasizes the integration of cities on a much broader scale, especially in terms of its spatial aspect. The result is substantively the same as what is caused by the process of urbanization, but since it covers a broader regional spatial scale, the impact will also be spatially regional in terms of both physical, economic, cultural and social spatial (Yunus, 2006).

The most obvious impact seen from the megapolitanization process is the occurrence of a very broad conflict of interest including in the planning of GOS as part of regional spatial planning. A broader discussion of conflicts of interest in spatial planning, by Yunus (2006) is then divided into several discourses that need to be examined, namely: (1) inter-temporal conflict; (2) inter-space conflicts; (3) inter-regional conflicts; (4) interpersonal conflict; (5) conflicts between institutions; (6) conflict between person and institution; (7) conflicts between individuals and community groups; (8) intergroup conflicts in society; (9) economic conflict; (10) political conflict; (11) cultural conflicts; (12) religious conflict; and (13) land use conflicts. Each type of conflict can display a combined form, so that the problems that arise become increasingly complicated.

The development of an area, including GOS, will certainly go through a very diverse process starting from the planning, implementation and supervision stages, where this process is very important and decisive, whether it develops in a better direction or instead falls into a worse condition. Based on observations, it can be explained that the violation emergence of the legal product in the form of local regulation (so called Perda) Number 27 of 2011 which regulates GOS in Denpasar City begins with a conflict in land use. This is evidenced by the widespread GOS functions transfer into a built environment. Spatial regulations must submit to and succumb to conflicting interests, marked by the expanded land use functions which have led to the GOS 
displacement as one of the public space typologies where people move.

After being explored in more depth, the emergence of conflicts in land use is triggered by the economic interests hegemony supported by political power over socio-cultural values of society. Economic conflict occurs because economic benefits consideration is used as the main reason in determining the direction of policy. This reason is actually has truth, because in the urban development dynamics, economic factors must be answered from the beginning before moving on to the next factors. This situation is complicated because in the determining policies about GOS process, the insistence of various economic interests contributes even frequently to being decisive without considering the region wider spatial needs. This economic conflict will continue and be made a correction if there are practices that violate the GOS provisions that have been set.

Political conflict will generally be related to governance. This is because in the process of urban development is not only limited to physical spatial, social, economic, and cultural issues only but in it will be followed by policies in governance as well. The political system in the policies form decided by the government in spatial development will also connect the economic system and the socio-cultural system. By positioning planning politics as a process in formulating all government policies regarding GOS planning in Denpasar City, it will be very possible for conflicts of interest to arise in the government environment, both in the internal legislature and between the legislature and the executive. And what needs to be observed is that this political conflict is also very vulnerable when GOS policy in Denpasar City is in direct contact with other regencies.

Meanwhile, cultural conflict is a form of clash between different cultures, which in this paper refers to Balinese culture as a fundamental foundation for regional spatial development. Cultural factors are important because living a life requires a way of life that will become a tradition or culture. GOS planning in Denpasar City should start from this cultural foundation, considering culture is the broadest theme and its relationship is very close to the natural environment and community social life. Conflict of interest occurs when the GOS policy which should accommodate the community cultural activities is defeated by the need for land for other activities which are considered more profitable.

\section{Consequences for the existence of green open space (GOS)}

Planning is setting a goal and choosing the steps needed to achieve that goal. During the process, planning will contain activities in the form of thought, calculation, selection, determination, etc. which are all done in order to achieve certain goals. Thus, planning is a decision-making process on a number of alternatives regarding the goals and ways that will be implemented in the future in order to achieve the desired goals, as well as monitoring and evaluating the results of their implementation in a systematic and sustainable manner (Tarigan, 2012).

Spatial planning policy in the GOS allocation context, should be carried out by considering the functions of cultivation and protection harmony and balance of functions as mandated by Law Number 26 of 2007 concerning Spatial Planning. for Denpasar City, socio-cultural considerations should get a larger portion with the uniqueness of social culture as the spatial development basic foundation. However, with the conflict in land use which is marked by rampant violations of the GOS provisions as regulated in local regulation Number 27 of 2011, it is an indication of problems in GOS planning policies in Denpasar City as shown in Figure 2.

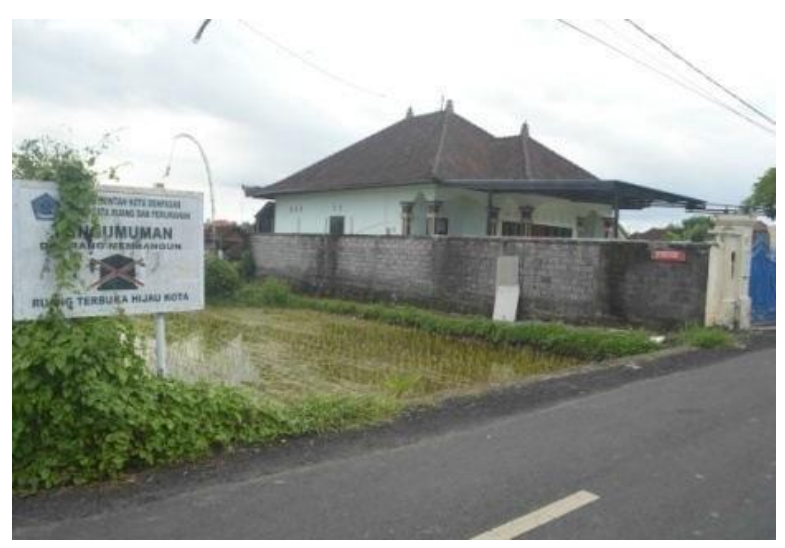

Figure 2. Violation of the city green open space area on Suradira Street, Denpasar

The marginalizing sustainability phenomenon of the GOS of the city is influenced by two factors:

(1) technical factors, namely the seriousness of the government in maintaining consistency in GOS management including green budgeting GOS; and (2) non-technical factors, namely 
stakeholder awareness to monitor and control the GOS utilization direction from market economic demand pressures on spatial politics (Widiatmaka and Hardjowigeno, 2007). In an almost similar context, Suartika (2010) mentions the reality in general in the field, lands that are vulnerable to being eliminated are strategic lands that have a buffer function of environmental order and cultural interaction patterns. This is in line with the theoretical studies conducted by Keizer, Godschalk, and Chapin (1995) in Suartika (2010) which emphasizes the trends in land use show a tendency for sectors of social and environmental protection, which are marginalized by land needs for economic activity. Land for these two interests tends to be converted and then eliminated to accommodate the land needs raised by other sectors.

Within the regional spatial planning framework, Denpasar City is in dire need of the existence of the GOS availability which ideally refers to its function as one of the community cultural activities. The insistence of the city physical development with economic and political interests that penetrated into all sectors of life, is believed to be the trigger for the legality of the GOS removal practices in a wild and uncontrolled manner. Because one of the GOS functions is to accommodate the community cultural activities, this will lead to conflict and become a threat to the basic structures sustainability including culture, which is precisely the regional spatial development main foundation.

\section{CONCLUSION}

During the process of urban development, the conflict of interest existence is a necessity because it covers a wide spatial area with a population and diverse occupant characters. Each of these interests will bring up different types of conflict and the discussion becomes more complicated when displaying a combined form. However, this needs to be understood so that conflict management can lead to conflict resolution efforts. The conclusion from the study with the three sub-topics discussed above, presumably has provided a complete conflict of interest description in the GOS planning as one of the public space typologies in spatial planning and formation context in Denpasar City.
First, as a basic element of regional spatial planning, Denpasar City Government makes GOS as one of the regional spatial planning basic elements through local regulation (so called Perda) Number 27 of 2011 concerning the Denpasar City Spatial Plan (so called RTRW). The GOS existence and position is very significant, in its planning in many cases it is actually made sober with the aim of only fulfilling the GOS proportion provisions $30 \%$ and GOS public $20 \%$ of the city area. GOS planning is unintegrated with spatial planning as a whole, causing the GOS position to be very weak as evidenced by the high change in GOS function to the built area.

Secondly, every policy decided by the government is the result of synergy, compromise or even competition - in this study the term is conflict-between ideas, theories, ideologies and interests. Regarding this interest, the regional development including GOS planning will go through a very diverse process and it is very important and determines the direction of its development. The violations emergence on the GOS functions transfer into a built environment in the Denpasar City, preceded by the conflicts existence in land use triggered by the economic interests hegemony supported by political power on the socio-cultural values of society.

Third, spatial planning policies in the GOS allocation context, should be carried out by considering harmony, alignment, and balance of cultivation functions and protection functions. And for Denpasar City, socio-cultural considerations should get a bigger portion with the social culture uniqueness as the spatial development basic foundation. But unfortunately, the demands of the city physical development with economic and political interests that penetrated into all sectors of life, became the trigger for the legality of the GOS removal practices in a wild and uncontrolled manner. Considering the GOS function is to accommodate the community cultural activities, this then creates conflict and becomes a threat to the basic order sustainability including culture, which is precisely the regional spatial development main foundation.

\section{RECOMMENDATION}

GOS has a strategic and very important role in spatial planning and physical spatial formation, 
both at the global, national and local levels. If people want to stay afloat with the unique socioculture as the basic foundation for planning and forming regional spheres, then there is no time for those who have an interest in GOS to conflict. All parties must be responsible in maintaining the GOS existence with all the provisions and activities that take place in it. The government as the power holder has three fundamental obligations, namely: (1) repositioning the urban development direction that guarantees the GOS availability in an ideal and sustainable manner; (2) positioning the uniqueness of socio-culture as the main consideration in planning GOS that is integrated with the regional spatial planning system as a whole; and (3) preparing a set of regulations as a form of protection against the GOS existence from the worst effects of capitalism with all its commodification forms.

Considering the importance of the issues discussed in this study, in the end it was emphasized the need for further research which specifically and deeply discussed the GOS in Denpasar City. The results of the study are expected to be input for the government as a policy maker, so that this issue can be ideally used as reference material in any regional and national spatial development policies, as well as sustainable GOS planning and development policies.

\section{ACKNOWLEDGMENT}

The implementation of this research activity certainly cannot be separated from the help and attention of various parties. Therefore, thanks and highest accolades were conveyed to the Directorate of Research and Community Service Directorate General of Research and Development of the Ministry of Research, Technology and Higher Education through the Institute of Research and Community Service, Udayana University for the opportunity given to carry out research in accordance with the Research Contract Number: 171. 19 / UN 14. 4. A / LT / 2018, dated February 19, 2018.

Thank you to the Dean of the Faculty of Engineering, Udayana University and the lecturers of the advisory team (Promoter and CoPromoter) in the preparation of the dissertation, for guidance, encouragement, recommendations and approval, so that this Doctoral Dissertation
Research can be carried out well. The appreciation and thank you as well to colleagues in the Major Architecture, Faculty of Engineering, Udayana University and students as field staff for all their assistance and cooperation.

\section{REFERENCES}

[1] Aminah, S. "Konflik dan Kontestasi Penataan Ruang Kota Surabaya", MASYARAKAT: Jurnal Sosiologi, vol. 20, no. 1, Jan. 2015.

[2] Anonim. "Undang-Undang Republik Indonesia Nomor 26 Tahun 2007 tentang Penataan Ruang”, 2007.

[3] Anonim. "Peraturan Menteri Dalam Negeri Nomor 1 Tahun 2007 tentang Penataan Ruang Terbuka Hijau Kawasan Perkotaan", 2007.

[4] Anonim. "Peraturan Menteri Pekerjaan Umum Nomor 05/PRT/M/2008 tentang Pedoman Penyediaan dan Pemanfaatan Ruang Terbuka Hijau di Kawasan Perkotaan", 2008.

[5] Anonim. "Peraturan Daerah Provinsi Bali Nomor 16 Tahun 2009 tentang Rencana Tata Ruang Wilayah Provinsi Bali Tahun 2009-2029", 2009.

[6] Anonim. "Peraturan Daerah Kota Denpasar Nomor 27 Tahun 2011 tentang Rencana Tata Ruang Wilayah Kota Denpasar Tahun 2011-2031”, 2011.

[7] Hakim, R. "Analisis Kebijakan Pengelolaan Ruang Terbuka Hijau Kota DKI Jakarta", Thesis Institut Teknologi Bandung, 2000.

[8] Carr, S., Francis, M., Rivlin, L. G. and Stone, A. M. "Public Space", Handbook. Cambridge University Press, USA, 1992.

[9] Darmawan, E. "Analisa Ruang Publik Arsitektur Kota", Badan Penerbit Universitas Diponegoro, Semarang, 2005.

[10] Moleong, L., J. "Metodelogi Penelitian Kualitatif", PT. Remaja Rosdakarya, Bandung, 1994.

[11] Mudra, I K. "Making Place for Cultural Legacies, Creative Culture, and the Tourist Development: Raging Depletion of Green Open Public Space in Bali", Proceedings Arte-Polis 6 International Conference Imagining Experiences: Creative Tourism and the Making of Place. 
School of Architecture, Planning and Policy Development, Institut Teknologi Bandung, 2016.

[12] Shirvani, H. "Urban Design Process", Handbook. Van Nostrand Reinhold Co, New York, 1985.

[13] Sriartha, I P. dan Windia, W. "Efektivitas Implementasi Kebijakan Pemerintah Daerah dalam Mengendalikan Alih Fungsi Lahan Sawah Subak: Studi Kasus di Kabupaten Badung, Bali”, Jurnal Kajian Bali, vol. 05, no. 02, Okt. 2015.

[14] Suartika, G. A. M. "Morphing Bali: the State, Planning, and Culture", Handbook. Lambert Academic Publishing, Germany, 2010.

[15] Suartika, G. A. M. "Lost in Translation: The Balinese Vernacular Open Space Tradition”, In: Suartika, Gusti Ayu Made. editor. Vernacular Transformations Architecture, Place, and Tradition. First Published. Pustaka Larasan in conjunction with Udayana University's Masters Program in Planning and Development for Urban and Rural Areas, Conservation of the Built Environment, and Ethnic Architecture, Denpasar, 2013.
[16] Suharto, E. "Kebijakan Sosial Sebagai Kebijakan Publik", Alfabeta, Bandung, 2008.

[17] Suparta, I K. "Alih Fungsi Lahan Ancam Jalur Hijau", (online):

http://antarabali.com/berita/23882/alih-

fungsi-lahan-ancam-jalur-hijau, 2012.

[18] Suparta, N. "Alih Fungsi Lahan Sampai 1.000 Hektar Per Tahun", Harian Umum Bali Post, hal. 7, 20 Maret 2017.

[19] Tarigan, R. "Perencanaan Pembangunan Wilayah", PT. Bumi Aksara, Jakarta, 2012.

[20] Widiatmaka dan Hardjowigeno, S. "Evaluasi Kesesuaian Lahan dan Perencanaan Tataguna Lahan", Gadjah Mada University, Yogyakarta, 2007.

[21] Yunus, H. S. "Struktur Tata Ruang Kota", Pustaka Pelajar, Yogyakarta, 2006.

[22] Yusuf, A. M. "Metode Penelitian Kuantitatif, Kualitatif \& Penelitian Gabungan”, Prenadamedia Group, Jakarta, 2014.

[23] Zahnd, M. "Seri Strategi Arsitektur 2; Perancangan Kota secara Terpadu, Teori Perancangan Kota dan Penerapannya", Kanisius, Cetakan ke-7, Yogyakarta, 2006. 